\title{
Did the Family Show Aunt Hatty Your High School Last Sunday?
}

The American high school buildings are one of the most unique, tangible assets of our culture. These buildings can become a major factor in implementing an expanded program of public relations involving more citizens.

RUSSELL E. WILSON

$\mathrm{T}$

HERE was a time in America, and perhaps you were a young highschool teacher then, when the long-awaited Aunt Hatty came to town to see the family, and the family, with rightful pride, drove Aunt Hatty out to see the high school. For in those days our people were building America-clearing new farms, building new towns and cities, and building the new high school which was likely to be the largest, and the best, and the most prominent, public building in town. Then there was no need for educators to be concerned about public relations for school buildings. In those days the people and all their country cousins looked up to see the column-and tower-decorated edifice on the hill and felt, with pride, that this was good. Did anybody in your town show anybody's aunt, or uncle, or cousin, your high school last Sunday? If so, what was their reaction?

Even until today, and into tomorrow, in the eyes of our citizens our high-school buildings are still the most visible, tangible part of every local school system, and the sight of them certainly still creates public reactions. Are these reactions as favorable today? Which are more accurate? Here are some pertinent facts about school buildings to help you judge:

1. Most high-school buildings in America, built during the 1910-1940 decades, were so extravagantly ornate and so wasteful of space in wall thickness, corridors, towers, and grand stairways that not one town in a thousand is wealthy enough today to duplicate that same type of high-school structure.

2. The costs of building indices reveal that school building costs have risen less in the last two decades than have the costs of any and all other types of public and private buildings.

Dr. Wilson is a Professor of Education and a Consultant on School Buildings at the University of Michigan, Ann Arbor, Michigan. 
3. The majority of new homes built in America in the last decade were sprawling, ranch style, one-story structures. These were more expensive to build than compact, box-like, two-story houses.

4. Conversely, one-story, spread-out high-school buildings are invariably cheaper to build, maintain, and operate than are compact, two- or three-story buildings; yet, the public frequently reacts violently and negatively whenever a one-story school building is proposed.

Isn't it fair to observe today that the variance between public reactions to school buildings and the facts of school building costs does suggest the quip, "Don't confuse me with the facts; my mind is already made up?" Since knowledge is a major ingredient in, and precedes, understanding, is not the major public relations problem concerning school buildings first, to equip educators with facts about buildings, and then to transmit such knowledge to our citizens? Is understanding even enough? Is there not an even harder task: To create emotional attachment to high schools, so that our citizens think and say " $m y$ school," rather than just "the school?" What are the ingredients of experience that cause people to say "my home" rather than "my house?"

Our insights into human behavior which provide answers to these questions can be our guides to a planned program of good public relations using our school buildings as a major tool in creating sound public support for our educational programs.

The very fact that our school buildings are prominent in the public view creates public relations, or public reactions. But in these days of a complex society, the automatic public reactions are not likely to be favorable to good support for our educational programs. Good school men realize that, in these times, our schools must compete actively for the attention and the affection of the general public, vieing with all the other institutions of society which seek public support. A ride past the local bowling alley on the way to the next PTA meeting will reveal to anyone the magnitude of the competition for the minds of men. Is it really reasonable to expect the man on the street to pay school taxes every year of his life, willingly and graciously, without knowing why or what the values are?

\section{Public Reactions to School Buildings Can Be Improved}

It is timely for educators to re-appraise their public relations programs regarding school buildings. The population increases and the shifting emphases in instructional programs of the past decade have created tax resistance pressures in most American communities against more school building tax dollars. In a very real sense, there is an element of tragedy and frustration in the popular impression that because new school buildings are more beautiful and more functional, they must be wastefully extravagant.

When educators today do re-examine the facts behind a public relations program related to school buildings, they will be pleasantly surprised. For once the educators will find that there is a good, solid, 
defensible story to tell the general public about education and tax dollars. When most school building projects are seriously and deeply scrutinized, it will be revealed that the taxpayers are getting more value out of school building dollars than they are for nearly any other product or service which they purchase.

Educators should welcome the task of assembling and analyzing the facts about school building costs, for these facts, when compared with other taxpayer costs, will speak for themselves. They can form a solid foundation for a good school public relations program that in most communities will assuredly improve public reactions to school buildings. However, hasty and superficial analyses of building costs will lead only to further public confusion and resentment. It is likely, though, that when educators improve the reactions of the public to school building costs, some "halo effect" can be expected which will improve the public's reactions to other educational costs. It must be understood that the negative public reactions to school buildings involves factors much more fundamental to the welfare of society than just tax dollars.

While later portions of this article will describe several specific recommendations regarding school buildings and public relations, at this point it seems more important to establish three broad, general concepts as the basis for public relations programs involving school buildings. These broad concepts are directly related to the deeper public concerns about school buildings. Within this context, no differentiation is intended between high schools or other types of schools:

First, educators should communicate the positive story of the wisdom and economy of tax money invested in school buildings. The factual record of the past decade regarding the true costs of school buildings as compared to other types of building costs is a good story which will stand on its own merits. It is a story that educators can be proud to make known to the general public.

Second, educators should implement the community school concept which will bring about multitudinous uses of school buildings by all citizens. The implementation of the community-school concept will multiply the uses of school buildings by ever-increasing numbers and segments of the general public. Since in most communities in America its public school buildings are the largest and most expensive capital investment paid for from local tax sources, increased uses of these investments are socially, educationally, and economically sound. It seems axiomatic that the public reaction to wiser uses of community investments will be positive.

Third, educators should establish, in the minds of the public, the direct, functional relationship which exists between school building facilities and the kind and quality of the instructional programs. The direct and functional relationship between instructional programs and school building facilities must be explained and demonstrated repeatedly to the general public. This third general premise for a public relations pro- 
gram involving school buildings warrants the most thoughtful and persistent attention of all, for the most widespread and the most negative public reactions to school building tax programs have, in the main, been caused by sharp differences of opinion over the kinds and the extent of school facilities to be built. More careful analyses of the causes of failure of school bond issues frequently reveals that the fundamental issue revolves around disagreement over the basic purposes and the worthwhileness of public education.

It is conceded that tax groups and other pressure groups frequently exert sufficient influence to defeat numerous local school building programs. However, at the present time, the largest single group in most American communities is composed of the voting-age parents of school children. It is this majority group and their children who benefit the most, and the most directly, from expenditures for public school buildings. Yet it is saddening to record that the majority of school bond issues are lost not primarily because some eligible-to-vote parents frequently vote, "No," but more significantly because, in most school bond elections, the majority of this parent group never even went to the polls.

Public apathy, disinterest, and inertia are the largest enemies. Is it not, then, the essence of clarity that the major emphasis of public relations programs involving school buildings must be directed at establishing in the minds and hearts of the mass public the direct relationship between the instructional program and the appropriate physical facilities which implement it?

Until there is general public acceptance of the kinds and the extent of the instructional programs to be offered in a local community, it is more than futile to try to "sell" school building programs; too frequently it is disastrous. To be specific, when a proposed school building is at an early stage of consideration, there may be some general public discussion and some mildly expressed disagreement about "expanding the home-economics program," or "increasing the opportunities for creative self-expression." More frequently, there is a complete lack of comprehension of the broad implications of these generalities for school building facilities, size, and costs. The volcano really starts to erupt when, a few years later, the building is opened to the public. For here to be seen, felt, and talked about is the concrete, tangible, permanent evidence of the underlying public disagreement over not truly the school buildings and their costs, but rather the purposes of public education itself. Herein lies the ingredient of the old saw about superintendents of schools: "Build a building and leave town."

\section{Some Specifics for Improving Public Attitudes}

The well established psychological basis for creating and changing public attitudes has applications for public relations programs involving school buildings. The specific task in this instance is to create the public feeling that their school house is their school home. Simply, but 
truly, the public must then spend time in their school home; must feel welcome in their school home; must participate in decisions regarding their school home. School policies and programs can be structured to cause these kinds of social behavior patterns.

Local school leaders who have improved their school building relations programs report success with these specific techniques:

1. Create a glowing sense of pride in your school staff and students. First, in their educational achievements and second, in the contribution that the school building makes to their welfare. Structure the activities of the staff and students so that through involvement, through acceptance of responsibilities, through evaluation, and through feeling of belonging, these key people develop a feeling that their school is their home-away-from-home.

2. Adopt and promote building use policies designed to increase wider use of school buildings by all segments of the public. (An examination of some local school district policies suggests that they have been designed primarily as an additional source of school revenue.) The most successful building use policies are based upon: (a) implementing the community school concept, (b) expanding the school day and the school year, and, (c) devising special community events which utilize school buildings more fully.

Numerous, specific examples of these kinds of programs are recorded in the yearbook of the National Society for the Study of Education devoted to the "Community School." The Mott Foundation in Flint, Michigan, has recorded in their publications the successes which can be achieved in better uses of school buildings. The special program of "Grandparents Day" in Lansing, Michigan, is another successful way to bring hundreds of citizens into the school classroom, many of them for the first time in decades. The "Lighted School House Program" is a nation-wide success in our neighboring democracy, Canada.

3. Establish a "Welcome to your School" program to implement building use policies. It simply is not sufficient merely to issue an invitation to the public to visit their schools. Citizens should be welcomed back into their schools as long-absent partners in the joint home-and-school task of educating youngsters. They can be made to feel more welcome by: (a) locating public parking lots easily accessible to school entrances; (b) erecting readable street signs directing visitors to open parking lots; and (c) posting signs inside school entrances which welcome visitors and which direct them to the office, to information desks, to places of public use.

But a "welcome" is never complete without personal contact. A friendly face and a spoken word of welcome is just as important, and just as effective, with visitors to school buildings as it is with visitors to private homes. The chill that most school visitors feel when they step inside a school building stays with them a long time. There is substantial public relations value in instructing hall monitors, custodians, and teachers to seize the initiative, to step forward and greet visitors to school buildings as readily as they would visitors to their homes.

4. Give all school visitors some prepared materials to take with them when they leave. Some food for thought is just as important a "gift" to give a school visitor as are the favors and food which are offered to home visitors. The school gifts may be simply: school newsletters, high-school handbooks, school board policies, courses of study, and sample instructional materials. The value of a 
gift is measured not by its price but by its meaning, so give them something to remember you by-and they will.

5. Personalize the facts and story of your school building. Arrange for your faculty and your students to know the facts. Is it more important and meaningful to your school patrons to know that:

a. The school swimming pool cost them a lot of money, or that drowning is a major cause of death of teenagers and that each year your school teaches hundreds of their students to swim with safety?

b. There is a commercial department in your building with thirty typewriters in it, or that each year your school equips eighty students to earn a living and help support a family?

Names make news and identification builds support; be sure the successes of your students and your staff are identified in printed stories and public conversations with the name of your school building.

6. For real impact, occassionally violate one of the "rules" of polite society. Don't stage all of the public meetings in the "parlor." When some of the rooms in your building are instructionally impassible, or poorly lighted, or poorly furnished, or are unsafe, violate the tradition of party planners and arrange to hold public meetings in your "bad" rooms instead of your "best" rooms. When the public is invited to see only a nice lawn, or a polished gym floor, or an attractive library, or an orderly office, it is inconsistent and unreasonable to expect citizens to feel keenly about unseen, inadequate classrooms and laboratories. It is even more pointless to expect citizens to take action about unknown hazardous boiler rooms, or unsafe ventilating systems, or unsanitary shower rooms, or stinky locker rooms.

\section{New Buildings Demand New Approaches to Public Relations Programs}

When the word is out, the public screams, while the educators cringe. At the fateful moment when the news breaks-"It is reliably estimated that the proposed new high school for Ourtown will cost $\mathrm{X}$ millions of dollars"-it is already too late to talk about an effective public relations program for a new school building. For "timing," not "technique," is the crucial element.

When you and your community are to "experience" a new high school, the timing of your public relations program will determine whether you and your school patrons are to experience the normal, parental joys of a happy, healthy new baby, or the depressing ugliness of a stillbirth. The planned gestation period for the development of a new high school is rarely too long and is most frequently much too short. The correct time, then, to activate your public relations program for a new high school is the precise moment that you conceive the need for a new building. For all too commonly it is a paralyzing shock to both parties when the school patrons and the educators first intercommunicate their own personal visual perceptions of what a new high-school building should be like. After the interested parties have listened through the routine of "You tell me your dream and I will tell you mine," the educators are apt to feel that the patrons were describing an igloo and 
the patrons frequently conclude that the educators were imagining the Taj Mahal.

Five long, busy, throughtful years is about the right amount of time in which to conceive, plan, convince, and build a new high school. With sufficient time, a well-founded public relations program usually insures future happy occasions for both educators and taxpayers.

Some of the essential ingredients of a successful new building public relations program have been found to be: first, a well-organized cooperative school building planning process; second, a broad, two-way, public information program; third, educational specifications for the building project acceptable to the educators, the board of education, and the school patrons. Each of these major ingredients warrants additional explanation. But, first, some sights should be set.

The occasion of building a new high school is a rarity in the educational history of even large communities. It is well to break our chain of thought and ponder for a moment upon the uniqueness of this community opportunity. For truly, the educational scope and the philosophical implications of a new high school are sufficient to challenge all school faculties to their greatest professional efforts, while the magnitude and cost of the project are sufficient to capture the focus of attention of even the most apathetic citizenry. The occasion of a new high school is usually the greatest opportunity educators have to take giant strides forward in improving the educational programs under their directions. The simple, little, white lines on the blue-prints approved by the educators are transformed all too soon into reality as strong as bonds of iron around the educational opportunities of several succeeding generations of children. Should we not hope that the bonds of iron will have the characteristics of imagination, creativity, and loftiness like the Eiffel Tower and the Big Mackinaw Bridge rather than the human bondage of handcuffs?

But, to return to the major ingredients of a public relations program for a new school.

First, another comment is in order on the cooperative planning process. Numerous professional publications describe fully the operation and purposes of cooperative planning. Here it is essential to note that the primary purposes of involving large numbers of school personnel, consultants, and lay citizens in discussions of modern school programs and the requisite physical facilities are: (1) to secure the general public relations benefits of involvement of people, which are discussed in other sections of this publication; (2) to seize upon the uniqueness of a new high school to make major progress in up-dating the instructional program; (3) to up-date both educators and laymen regarding modern school building techniques and practices.

Second, another comment on a two-way communication system between the cooperative planning groups and the citizenry at large may help to emphasize this process. It is less than effective for a high-school planning group to retire from public view and, months or perhaps years 
later, spring forth upon the unsuspecting public with fully developed plans and financial programs for a new building. A play-by-play description of planning developments must be registered with the general citizenry. Public reactions and side-line coaching while the game is being played must be accepted and countered. Other sections of this publication explain the techniques of such communication systems.

Third, the public relations value of educational specifications is so great that further comments are in order. The context of the matter is that school buildings should be built three times: once, as described in words, in a document called "Educational Specifications," as a functional school building to house a locally accepted educational program; a second time, as described and sketched in the specifications and drawings developed by the architect; and again, as a reality of physical materials in the completed building.

The point of this discussion is that the time to stage the great debates and to arrive at the essential compromises over the building, its type, its size, its cost, and its facilities is during the planning period devoted to the preparation of the educational specifications. And this is the least expensive time to do it. When plans have been drawn and construction contracts let, "building changes" are inordinately expensive. It can be catastrophic public relations-wise to let the public "discover," during the Open House, new and wondrous facilities in the building which it had not expected. Therefore, it is sound to use the "Educational Specifications," as officially adopted by the board of education, before building plans are drawn, as the major communication device between educators, planning committees, and the public-at-large.

\section{Some Specifics for Modern School Buildings}

\section{On Achieving Beauty}

Like the pervading, incessant beat of a tom-tom, the theme surges through the community, "Yes, the new high school is beautiful, but it must be expensive. No, on second thought, it is outright extravagant." Larry Perkins, the creative school architect from Chicago, tells a delightful story about two young women. The gem of it may still shine through the inept retelling of it here. Imagine, if you will, two young women in the bloom of early maturity. Both are of the same age, both of the same weight, both built of the same materials, and both worth about a dollar or two if reduced to basic chemicals. Imagine further, if you can, one of these young women as the beautiful girl of your dreams, and the other young woman as the ugly witch of your nightmares. Is not then the essence of beauty in the strategic placement and arrangement of rather small bits of identical materials and colors? The costs of the building materials are the same; extravagance is an extraneous issue. Beauty in school buildings is the one quality that comes for free from the creative imagination of competent architects; everything else about buildings costs money. 


\section{On Evaluating Costs}

Since one of the major public reactions to new schools is over costs, it is incumbent upon the school leaders to meet its "cost" problem head-on. Previous sections of this section noted that: (1) the nation-wide analysis of new school building costs is an optimistic story, for new schools cost less, comparatively, than do other types of buildings; (2) it must be recognized that new school building taxes are most often the largest direct capital expenditure from local taxes; (3) the major and most controlling factor in building costs is the kind and the extent of the instructional program to be housed, and it is not types of construction nor kinds of building materials. Thus the public relations program designed to win community support for school building costs must be based directly upon the curriculum and population requirements.

The good public relations story about cost is found, then, in measuring the dollars invested against the yardstick of how well the building meets the instructional needs of the school program and how well the building helps prepare youth for life. The 1960 yearbook of the American Association of School Administrators, which is devoted to school buildings, contains an exhaustive treatment of some of the more popular mechanical formulas used to analyze school building costs. It is made clear that superficial analyses of costs expressed in square footages or cubages or in quality levels of materials are frequently more misleading than they are informative. Bluntly, when school officials compare their school building costs, one against the other, by a measure such as squarefoot costs, and try to take satisfaction from having a lower dollar figure, they are indulging in a pure fantasy of over-simplification.

Yes, school officials should compare their building costs with those of other communities and, yes, school officials should analyze their school building investments item by item and facility by facility. Yes, school officials should seek economy in materials and building techniques. In fact, school officials are urged to do a more thorough job of cost analysis by using good methods, such as those explained in the AASA yearbook. Through the use of these comprehensive methods of building cost analyses and comparison, educators can have a good, sound story to tell the taxpayers. However, like so many other material items-homes, autos, or motor boats-the true and complete costs of school buildings can never be known until all the expenses have been counted. The original contract cost is only a down payment. It is only a small fraction of the total expenditures on a high-school building which is likely to be used and maintained for over fifty years. The real costs cannot be totaled until the building is abandoned.

\section{On Improving Communications}

More than half of the school building bond issues presented to the public each year are passed successfully. Some reasonable inferences from this fact are that the general public wants good schools for the children of this nation and that the general public still has a great meas- 
ure of faith in our educational profession. Conversely, our professional leaders thus have the responsibility to communicate to the public how school buildings do help provide good education. Many schoolmen have had successful experiences in learning how to improve their communications about new buildings. Some of their techniques are:

1. Distribute and discuss widely the proposed educational specifications for each new building project, for these educational specifications contain all of the final decisions and final answers regarding the nature and scope of the project. Previous sections of this article have discussed this more fully.

2. Prepare and distribute building brochures describing the building, building plans, and financial data. The most successful brochures include such items as:

a. Building costs expressed in terms that are meaningful and easy to comprehend, rather than stating that the building costs $\mathrm{X}$ million dollars, or that the pool cost so much. Costs are related to the public's normal buying habits. For example, costs may be expressed as, "The average home owner who is buying his home on a mortgage will have his monthly payments to the bank increased by so much per month."

b. Prepare a first and then a second brochure. The second includes forthright answers to the many questions collected from the early groups of visitors to the new building.

c. Evaluate carefully the words used in names, labels, room signs, and designations on the building plans and in the actual building. Public reactions are emotionally charged by words themselves. There are significantly different psychological reactions to signs which read, Teachers Workroom instead of Staff Lounge; or Physical Training Room instead of Game Room, or Dining Room instead of Cafeteria.

3. Prepare the staff to communicate effectively with the general public and the student body about the new building. The training program usually includes: (a) staff meetings with the school architect in the completed building to explain the reasons for the features and the materials, etc.; (b) staff visits to other new school buildings with which the general public is likely to compare the local building; and (c) staff briefing sessions on likely public questions and answers about the building, such as those to be included in the building brochure.

4. Organize a series of open house programs rather than just a single dedication day. The series is established to appeal to various special interest groups, such as: (a) school board members and other public officials; (b) planning committee members; (c) local staff groups from other buildings in the school system; and (d) parents and selected community groups, such as businessmen, employers, and civic associations. Well informed guides and supplies of printed materials contribute to the success of these ventures.

\section{School Buildings Are Here To Stay}

Of all the activities in which the American people engage as they live and work together in their local communities, counties, and states, perhaps none expresses in material form, so many aspects of our culture as school-building construction. With its roots deeply embedded in the past, the school building is a symbol of the ideals of a free, self-governing people. This was true of the rough $\log$ cabin that housed a meager educational program in the frontier 
community. It is equally true of the well-planned school plant which houses a comprehensive educational program in a present-day suburban school district. Its classrooms, its libraries, its laboratories, and its shops, filled with eager, inquiring children and hopeful, questioning youth, are as alive to the present as a busy street or a buzzing industrial plant.

With a look toward the future, the school building reflects the ambitions, the hopes, the aspirations, and the dreams of a people that is striving to move forward and upward to a way of life that is better, fuller, richer, and more rewarding than that which it now knows. At its best in form and appearanceas it stands majestically on the highest hill top in the village, or nestles quietly and unobtrusively on the bank of the small stream in the valley, or affords a pleasing contrast to the dull, monotonous tones of a tenement district in a congested metropolitan area-it is an expression of the aesthetic values of the people and their sense of what is pleasing and beautiful.

This sensitive and encompassing statement from the 1960 AASA yearbook sets the task of public relations programs involving school buildings. The social responsibility of all educational leaders is clear: first, to understand and believe in this statement themselves and, second, to transmit such beliefs to all of the general public. All school building public relations programs should be both directed to and evaluated by these nation-wide goals.

OFTEN THE MOST EFFECTIVE presentation of solid student achievement is through the "local boy makes good" approach.

Many high schools each year invite a graduate who now has a responsible position to address the student body. Bridgeport (W. Va.) High School selects a former graduate for the importance of the contribution he or she is making to the world.

Other schools have alumni speak at a special student assembly during the school year.

Whenever a product of the local schools can be heralded, parents and the most reluctant taxpayers are helped to see that their tax dollars invested in education have a solid return. They have visual proof that their investment has produced worth-while citizens. 